\title{
O SISTEMA ELEITORAL BRASILEIRO. ELEIÇÕES GERAIS 2010/ELEIÇÕES MUNICIPAIS 2012
}

\section{0 cenário eleitoral e sua anatomia}

\author{
Brazilian electoral system. General elections 2010/Municipal elections 2012 \\ The electoral scene and its anatomy
}

\section{Monica Herman Caggiano}

Livre-Docente em Direito Constitucional pela Faculdade de Direito da USP. Presidente da Comissão de Pós-graduação e Professora Associada do Departamento de Direito do Estado da Faculdade de Direito da USP. Professora Titular de Direito Constitucional e Coordenadora do Curso de Especialização em Direito Empresarial da Universidade Presbiteriana Mackenzie. Assessora Especial do Governador do Estado de São Paulo (2006). Procuradora-Geral do Município de São Paulo (1995-1996). Secretária dos Negócios Jurídicos do Municipio de São Paulo (1966). Procuradora do Município de São Paulo (1972-1996).

ÁREA DO DIREITO: Eleitoral; Constitucional

Autora convidada

Resumo: 0 presente artigo, tendo em vista a aproximação das eleições municipais de 2012 , nos remete a uma leitura do desempenho da máquina eleitoral nas eleições gerais de 2010. Analisando criticas, abusos e o eleitorado, questiona a concreta realização do sufrágio e a solidificação das instituições e da realidade democrática a partir da Constituição de 1988.
ABSTRACT: With the forthcoming of the Brazilian local elections, this article intends to analyze the Brazilian electoral system on 2010. Analyzing critics, abuses and the electorate, the manuscript questions the full realization of the voting process as well as the concretion of the republican institutions and democracy from the Constitution of 1988. 
Palavras-chave: Corpo eleitoral - Eleições gerais de 2010 - Eleições - Voto - Representação política - Eleitor-cidadão - Eleições democráticas - Partido político - 0 eleitor em relação ao partido - Cidadão-eleitor e sua postura eleitoral - Sistema eleitoral - Proporcionalidade - Fenômenos patológicos.

\begin{abstract}
KeYwords: Electorate - General elections of 2010 - Elections - Vote - Political representation - Elector - Citizen - Democratic elections - Political party - Electoral system - Proportionality.
\end{abstract}

SumÁrio: 1. Nota introdutória - 2. A democracia brasileira. Tipo - 3. 0 poder de sufrágio I: quem vota? - 4.0 poder de sufrágio II: a candidatura - 5. Candidatura e reeleição - 6 . Candidatura em coligação - 7. 0 sistema eleitoral: ponto de tensão.

\section{NOTA INTRODUTÓRIA}

O momento de intensa ebulição que precede qualquer pleito eleitoral induz naturalmente ao exame deste sofisticado, complexo e polêmico momento em que a cidadania assume e exerce sua primordial função, a de escolher os seus representantes, os denominados decision makers, aqueles que, por delegação da soberana vontade popular, expressa pelas urnas, serão os responsáveis pelas políticas públicas produzidas e operacionalizadas em prol do progresso e do desenvolvimento de toda a sociedade.

É neste passo que, a aproximação das eleições municipais de 2012, passa a impor uma leitura mais atenta do desempenho da máquina eleitoral nas eleições gerais de 2010. Apurar os acertos, analisar as críticas, investigar os abusos, identificar a densidade da participação do eleitorado, questionar em que medida o poder de sufrágio encontrou campo hábil a sua plena e concreta realização.

A missão vai além. Porquanto a proposta consubstancia-se em reapreciação dos resultados da consulta de 2010, passando pelo viés da solidificação das instituições e consolidação da realidade democrática plasmada a partir da Constituição de 1988 e, nesta perspectiva, o passado e o presente permanecerão sob a mira deste estudo que buscará perquirir tópicos espinhosos do nosso cenário eleitoral, a exemplo da participação partidária, a fidelidade, o espectro das coligações, o status do candidato e a liberdade para o seu discurso e caminhada na conquista do voto. Enfim, os temas eleitorais de elevada inquietação de ontem e de hoje marcarão presença na perspectiva de oferecer ao leitor uma visão mais clara das nossas técnicas eleitorais e do seu efeito sobre o eleitorado e a voz das urnas. 


\section{A deMOCRACIA BRASILEIRA. TIPO}

O Estatuto Fundamental de 1988, reflexo do movimento de abertura política e do impacto das multifárias ideologias e posturas políticas emergentes no cenário constituinte, proclama, logo no seu art. $1 .^{\circ}$, uma configuração democrática das mais amplas, plasmada nos princípios da soberania, da cidadania, da dignidade da pessoa humana, dos valores sociais do trabalho, da livre iniciativa e do pluralismo político.

Em verdade, o demos, na idealização dos constituintes, deveria estar presente no processo político decisional por via de variadas formas de expressão, envolvendo os mais diferentes setores da comunidade, ideia reforçada pelo dispositivo do art. 14 da CF/1988, que acabou por formatar um padrão democrático semidireto, inserindo todo um instrumental de participação direta e indireta no plano da discussão e deliberação política, in litteris:

"Art. 14. A Soberania popular será exercida pelo sufrágio universal e pelo voto direto e secreto, com valor igual para todos, e, nos termos da lei, mediante:

I - plebiscito;

II - referendo;

III - iniciativa popular" (grifos nossos).

A questão assume maior notoriedade na medida em que, hoje, com a evolução da teoria democrática e uma vez consagrada a estrutura decisional policêntrica deste modelo, o polo nevrálgico passa a se consubstanciar no tipo de democracia pretendido e, certamente, muito diferente será o papel reservado ao demos em cada uma das espécies da variada gama de fórmulas que podem ser edificadas.

Espinhosa, é certo, a tarefa de precisar o que se pretende por democracia. ${ }^{1}$ Daí a infinidade de tipos construídos. Nessa perspectiva, a mais breve incursão na obra de Giovanni Sartori ${ }^{2}$ ou de Leonardo Morlino ${ }^{3}$ nos posiciona diante de uma vasta produção tipológica, oferecendo categorias de tons e nuanças diferenciadas em razão da amálgama que lhes serviu de pauta. Morlino, em especial, desvenda os tipos da democracia formal, a democracia universal procedimental e a democracia procedimental. E Sartori, num elenco ampliado,

1. Ver neste sentido o nosso Oposição na política. São Paulo: Agnelotti, 1955.

2. SARtori, Giovanni. Teoria de la democracia. Madri: Alianza Universidad, 1987.

3. Morlino, Leonardo. Democrazie. Manuale di scienza della politica. Bologna: Il Mulino, 1986. p. 137. 
fala até em democracia social, democracia industrial e democracia econômica, alinhando-as à democracia eleitoral, à democracia referendaria, democracia participativa e democracia consociativa, esta última desenvolvida a partir dos registros de Lijphart, ${ }^{4}$ que, aliás, elabora um catálogo de 35 modelos diferenciados de organização e práticas democráticas.

Nessa vasta arena tipológica, releva notar que a notoriedade do problema gira em torno da identificação de quem - do demos - toma parte do processo decisional e como participa.

Os constituintes de 1988 desenharam um tipo híbrido a autorizar o demos, a tomar parte do processo decisional em distintos momentos, utilizando as variadas ferramentas com que foi contemplado. Foram tímidos, decerto, ao oferecer à participação política direta um colorido suave, deixando a cargo do legislador ordinário a regulamentação necessária para a eficácia das normas que preconizam o referendo, o plebiscito e a iniciativa popular. Garantiu-se, de início, somente a prática da democracia, na sua versão exclusivamente representativa. Gradualmente, no entanto, as instituições foram objeto de aprimoramento, alcançando-se o século XXI com um espaço alargado e múltiplo para a participação política, quer por via eleitoral, quer por intermédio de instrumentos de controle político e de participação direta, a exemplo dos plebiscitos e referendos já realizados.

De fato, consciente da sua relevância na produção da decisão política, $o$ eleitor, agora com poder de veto, exerce a cidadania por intermédio de todos os instrumentos que o novo constitucionalismo e a sofisticada tecnologia colocou à sua disposição. Ele comparece às urnas e vota; mas atua, ainda, por intermédio de mecanismos diferenciados: a ação popular, o mandado de injunção, o mandado de segurança coletivo, as célebres Adi's, as ações civis públicas. Enfim são ferramentas que autorizam a intervenção cidadã na implementação das decisões políticas fundamentais. ${ }^{5}$

De outra parte, o tomar parte na textura decisional se viu fortalecido com a realização de diferentes consultas populares, sendo o poder de sufrágio incrementado com a convocação do eleitor para se pronunciar sobre a questão do

4. Lijphart, Arend. Modelos de democracia. 2. ed. Trad. Roberto Franco. Rio de Janeiro: Civilização Brasileira, 2008.

5. Tais mecanismos, como apontado em nosso trabalho $O$ cidadão-eleitor, jogador com veto no processo eleitoral democrático, estudo produzido em homenagem ao Min. Victor Nunes Leal, impulsionaram e continuam alimentando o avanço do fenômeno da politização da justiça ou judicialização da política. 
desarmamento (o referendo de 2005), o problema do fuso horário que conclamou a cidadania do Acre a se manifestar por referendo, realizado juntamente com o $2 .^{\circ}$ turno das eleições de $2010^{6}$ e, por derradeiro, o plebiscito de 11.12 .2011 sobre a divisão do Estado do Pará, indicando um resultado contrário, com a manifestação de 66,59\% votos desfavoráveis à criação do novo Estado de Carajás e 66,08\% negando existência ao também novo Estado de Tapajós.

Não há que se ignorar, outrossim, o fato de a democracia hoje praticada vir pincelada com nuanças de participação direta do demos na confecção da lei. Embrionária e tênue o desempenho da iniciativa popular preconizada no art. 61, $\S 2 .^{\circ}$, da CF/1988. Todavia, a incursão do legislador popular no plano da produção da norma - expressão da vontade política - afigura-se de efetivo realce, na medida em que a ele são atribuídos dois relevantes documentos: a vedação do aliciamento (art. 41-A da Lei 9.504/1997 - Lei das Eleições, com a redação dada pela Lei 9.840/1999) e o advento da denominada Lei da "ficha limpa", LC 135/2010.

Impacto maior neste percurso de desenvolvimento da democracia brasileira, sem dúvida, deve ser atribuído ao sistema de partidos instalado pelos constituintes, fórmula que, se no começo conferia ao partido político o monopólio das candidaturas, ${ }^{7}$ inviabilizando a presença de candidatos independentes, contribuiu, num segundo momento, para um grau de fortalecimento significativo, posicionando-o como peça imprescindível no cenário da operação eleitoral, ou seja, para a escolha dos governantes/representantes. Passa o partido, isoladamente ou por via de coligação, a ser o responsável pelo registro dos candidatos que apresenta para a disputa dos votos, pelo desenvolvimento da campanha de divulgação a respaldar os seus postulantes e, mais que isso, assume a posição de detentor dos mandatos eletivos conquistados sob a sua legenda.

Com efeito, este robustecimento do partido político consolidou-se com o fim do jogo dos parlamentares trânsfugas, ou seja, sob o impacto da imposição de fidelidade partidária, estabelecida pela Res. 26.610, de 25.10.2007, do TSE. Diante da notória evolução da denominada dança das cadeiras e à vista da

6. Note-se a estreia do referendo - consulta popular - no âmbito das eleições de 2010, convocando-se o corpo eleitoral a se manifestar sobre uma decisão de perfil político. De regular uso no panorama norte-americano, quando juntamente com a manifestação eleitoral, direcionada à escolha dos Governadores de Estado, o eleitor é convidado a participar de consultas referendárias, no Estado do Acre, entre nós, foi concretizado um referendo acerca da mudança de fuso horário, por ocasião do $2 .^{\circ}$ turno da escolha do Governador do Estado.

7. Conforme disposto no art. $14, \S 3 .^{\circ}$, V, da CF/1988. 
inércia do Legislativo que, inobstante a inflacionária produção de projetos e substitutivos a enfrentar este delicado fenômeno, não logrou qualquer avanço em termos concretos, o TSE procurou oferecer solução, in concreto, decretando a possibilidade de perda do mandato eletivo na hipótese de abandono da legenda que suportou a candidatura. Praticamente extinto, por superado, restou o tema dos trânsfugas, o turismo interpartidário e o mandato parlamentar e executivo passaram a manter uma estreita vinculação com a agremiação partidária que promoveu a candidatura. ${ }^{8}$

Entre nós, pois, o partido também passa a ser reconhecido como mola mestre do processo eleitoral provocando uma nova postura do eleitor. Este, ao menos em princípio, é compelido a optar entre programas governamentais, plataformas habitadas por diferenciadas políticas públicas. Impôs, também, um determinado perfil ao candidato; este, se vitorioso, passa a ter uma tarefa consubstanciada na defesa da plataforma partidária oferecida no decorrer da campanha. O seu papel seria o de agente a serviço desse programa governamental, e, daí, a exigência da fidelidade que não lhe autoriza mais abandonar a legenda pela qual se elegeu.

Assim é que o modelo hoje subsistente no nosso cotidiano consagra uma fórmula democrática semidireta, com ênfase, contudo, para a modelagem de democracia pelos partidos. Consolida em favor do povo, do demos, a possibilidade de "tomar parte" na feitura da decisão política - fazendo prevalecer, contudo, o padrão da "democracia governada", 9 a ideia de autogoverno concretizada primordialmente por via de representação política e dos partidos que, a este passo, são erigidos a atores centrais da plataforma política, quer no momento eleitoral, quer ao longo do exercício dos mandatos.

\section{O PODER DE SUFRÁGIO I: QUEM VOTA?}

O tema revela uma das mais espinhosas facetas do espectro eleitoral, porquanto lida com o quadro de votantes. Quem vota? Qual a parcela do demos que participa do processo político? A quem é efetivamente atribuída a tarefa de escolher os representantes ou, ainda, de forma mais específica, a quem, no quadro da democracia representativa, é assegurado o direito de tomar parte do processo decisional. Esse específico espaço opera sob comando do cânone da autodeterminação, desenvolvido a partir do panorama doutrinário e jurisprudencial

8. Sobre o tratamento dado à questão da fidelidade partidária e histórico da solução oferecida pelo Poder Judiciário, consultar: Lembo, Cláudio (coord.). O voto nas Américas. Barueri: Cepes/Manole, 2008. Série Culturalismo Jurídico.

9. A tese da "democracia governada" vem desenvolvida por SARTORI, Giovanni, op. cit. 
germânico e que repousa sobre a necessidade de igual consideração de todos os cidadãos, no sentido do reconhecimento, pela ordem jurídica, da capacidade, igual, de participação na formatação da vontade coletiva a todos os membros da coletividade política.

E, como principal corolário desse princípio, a exigência do sufrágio universal, atingido por força de árdua e morosa caminhada. ${ }^{10}$

No panorama doméstico, benevolente foi o tratamento constitucional oferecido pelo documento de 1988, inserindo reduzidas restrições e integrando no corpo eleitoral os adolescentes e os analfabetos. Significativa, pois, a ampliação do corpo de eleitores, principalmente, no tocante a última das categorias mencionadas, onde localiza-se um não desprezivel aglomerado de 67\% de eleitores analfabetos ou que não concluíram sequer o primeiro grau.

Esta realidade é objeto de constante registro e mensuração, apurando-se no último pleito um contingente de 8.097.513 de analfabetos; um grupo muito maior, porém, de eleitores com: (a) o primeiro grau incompleto $(34,07 \%$ do total); (b) o segundo grau incompleto (18,10\% do total); (c) que apenas concluíram o segundo grau (12,10\% do total); (d) apenas 3,49\% do total apresentando conclusão do ensino superior.

Aliás, interessante rever levantamento realizado pelo TSE, publicado em julho de 2008, que revela:

\section{Estados com maior proporção do eleitorado com nível superior:}

$\sqrt{ }$ Rio de Janeiro $(5,41 \%)$;

$\sqrt{ }$ São Paulo (5,03\%);

$\sqrt{ }$ Rio Grande do Sul $(4,14 \%)$ e

$\sqrt{ }$ Santa Catarina $(4,01 \%)$.

Estados com menor proporção de eleitores formados:

$\sqrt{ }$ Maranhão $(0,93 \%)$ e

$\sqrt{ }$ Piauí $(1,34 \%)$.

10. No Brasil, em 1932, pelo Dec. 21.076, de 24.02.1932, acolheu-se o voto feminino, autorizando-se as mulheres que ocupassem cargos públicos o acesso às urnas. Com a Constituição de 1934, novo avanço: reduziu-se a idade mínima para o alistamento e o voto para 18 anos. Por derradeiro, foi a Constituição de 1946 que consolidou o sufrágio universal, introduzindo a obrigatoriedade de alistamento e voto para ambos os sexos aos 18 anos. Veja-se, nesse sentido: Caggiano, Monica Herman. Direito parlamentar e direito eleitoral. Barueri: Manole, 2005. 
Sob o particular prisma dos adolescentes, os dados oferecidos pelo mapa eleitoral divulgado pelo TSE em 2010, registram um reduzido - e cada vez menor - interesse dessa faixa etária em participar da seleção dos governantes. De 2008 a 2010 houve um decréscimo de cerca de 18\% em relação ao jovem eleitor entre 16 e 18 anos.

O marco de maior notoriedade na composição do corpo eleitoral brasileiro reside, contudo, na proliferação do voto feminino que aparece como predominante. Transcorridos 70 anos da sua inserção no corpo eleitoral, a presença da mulher acaba por superar o eleitorado masculino, representando $51,8 \%$ do eleitorado brasileiro (ou 70,4 milhões), enquanto os homens representam $48,1 \%$ do total (65,2 milhões). ${ }^{11}$ Surpreendentemente, porém, não há simetria quanto à participação feminina nos dois polos do sufrágio: ativo e passivo. No tocante à postulação de candidatura, tímida e reduzida a interveniência da mulher, inobstante o elenco de mecanismos idealizados pelo legislador no sentido de incentivar a sua atividade política, inclusive por intermédio do sistema de cotas, nos termos da Lei 12.034/2009 que até ampliou para 30\% e tornou obrigatória a presença da candidata-mulher nas listas. ${ }^{12}$

No entanto, nas últimas eleições gerais, pleito/2010, o quadro apresentava-se bastante restrito, candidatas à Presidência: 2; ao Governo Estadual: 18, ao Senado: 34, perante 231 do sexo masculino, à Deputada Federal e Estadual, apenas 4.098. Mas, oportuno lembrar que esta postura feminina retraída é notada na vida política brasileira em geral. Nos diretórios partidários, poucas são as mulheres que ganham postos diretivos e nos Parlamentos (federal, estaduais e municipais) a presença feminina, por ora, ainda se apresenta como raridade. Espelho deste quadro o próprio resultado eleitoral de 2010, seleção dos Governadores de Estado - panorama em que apenas 3 mulheres conquistaram o posto executivo. E, ainda que a título ilustrativo, convém recordar que, nas eleições municipais de 2008, de um total de 5.658 municípios brasileiros, em 41 deles havia a perspectiva de candidaturas exclusivamente femininas para o

11. De se registrar que o contingente masculino prepondera sobre o feminino tão só nos Estados de Mato Grosso, Pará, Rondônia, Roraima e Tocantins. UOL Notícias. Disponível em: [http://noticias.uol.com.br/]. Acesso em: 20.07.2010.

12. Há, em verdade, verdadeira pressão para a presença feminina nas listas partidárias. Assim não surpreende decisão do TSE que, por força do voto do Min. Caputo Bastos, confirmando sentença e acórdão do TRE-SP, impediu candidatura masculina à vereança, no Município de São José da Bela Vista, por não ter sido respeitada a porcentagem (REsp 31.058/SP, j. 22.09.2008). 
cargo de prefeito. ${ }^{13}$ Paradoxalmente, porém, uma mulher se sagrou vencedora na consulta de 2010, conquistando o posto de maior proeminência, o de Presidente da República.

De qualquer modo, os indicadores denotam um crescimento constante do corpo eleitoral brasileiro, de cerca de $4 \%$ a cada novo pleito. Nas últimas consultas, registrou-se - em um contexto de múltiplas constelações decorrentes de agrupamentos comandados quer pelo fator idade ou o sexo ou a instrução - um total de 125,9 milhões de eleitores em 2006, 130,3 milhões de eleitores em 2008 e 135,8 milhões de eleitores em 2010.

Participam, portanto, deste megaespetáculo eleitoral, exercendo o direito de sufrágio, os brasileiros natos ou naturalizados portadores dos seguintes requisitos e atendendo às condições a seguir expostas:

\section{Voto Facultativo}

\section{Voto Obrigatório}

$\sqrt{ } 16-18$ anos

$\sqrt{ }$ Analfabeto

$\sqrt{ } \mathrm{O}$ maior de 70 anos

$$
\sqrt{ } 18-69 \text { anos }
$$

13. Eis a íntegra da notícia veiculada no site UOL em 23.07.2008, às 19h24: "Em 41 municípios, só mulheres disputam prefeitura. O mais recente levantamento do TSE (Tribunal Superior Eleitoral) contabiliza 41 municípios no Brasil que podem ter unicamente mulheres concorrendo ao cargo de prefeito nas eleições municipais deste ano. De acordo com o Tribunal, o número ainda pode ser alterado com a chegada de novos dados sobre os pedidos de registro de candidaturas na Justiça Eleitoral. Dos 41 municípios em que somente mulheres disputam a prefeitura até agora, 10 têm apenas uma candidata. Paraíba é o Estado com o maior número de municípios onde só existem candidatas na disputa do cargo de chefe do Executivo. São sete ao todo. Em seguida vem São Paulo, com cinco municípios nesta situação. Empatados, Piauí, Bahia e Rio Grande do Norte têm quatro cada. E Minas Gerais e Alagoas têm três municípios cada um. No Brasil, o número de solicitações de registro de mulheres na disputa pela chefia do Poder Executivo Municipal nas eleições de 2008 é pequeno se comparado ao de pedidos de registro apresentados por candidatos homens ao mesmo cargo. São 1.580 pedidos de registro de mulheres contra 13.677 de homens. São Paulo e Minas Gerais, os dois maiores colégios eleitorais do Brasil e que detêm o maior número de prefeituras, foram ultrapassados pela Paraíba em número de municípios onde, até o momento, somente mulheres concorrem à prefeitura. Disponível em: [www.uol.com.br]. 


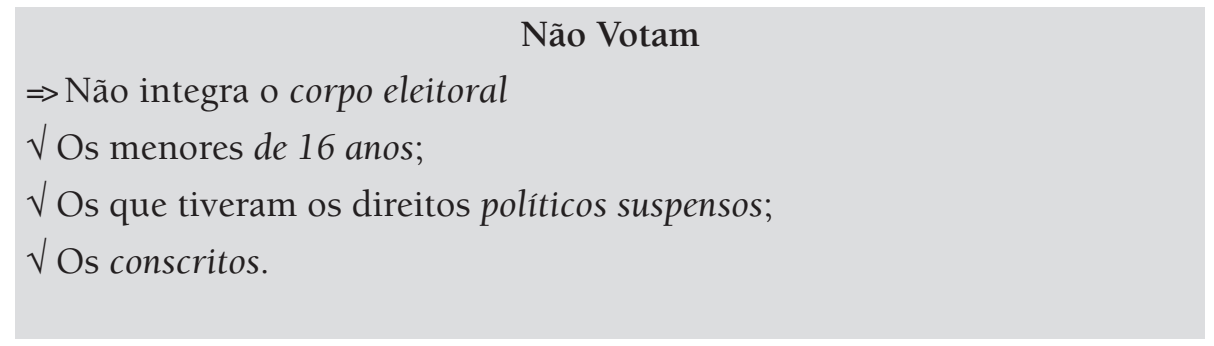

Por derradeiro, reparo merece o baixo índice de abstenção, de cerca de 18\%, fator que insistem em atribuir à obrigatoriedade do voto entre nós (consoante previsto no art. $14, \S 1 .^{\circ}$, da $\mathrm{CF} / 1988$ ). A verdade é que a justificativa - quanto à ausência na votação - importa num procedimento extremamente simples e as multas são irrisórias - isto quando não há anistia quanto às sanções eleitorais - o que, na prática do cotidiano, conforma o nosso voto como facultativo. O nosso eleitor, pode-se reafirmar - como anotado em outros trabalhos por nós desenvolvidos - já incorporou o papel de jogador com veto no mundo democrático.

\section{O PODER DE SUFRÁGIO II: A CANDIDATURA}

Não basta, no entanto, o amplo e expandido corpo eleitoral. O poder de sufrágio envolve e qualifica um verdadeiro status, o status civitatis. E este apresenta-se com duas diversas facetas. Alberga, numa dimensão, o direito de votar (ius suffragii) atribuído ao corpo eleitoral, e, de outro, a faculdade de ser votado, de disputar cargos públicos - (o ius honorum) - o direito à candidatura, compondo esses dois aspectos a capacidade política do cidadão. E, assim como em relação ao exercício do voto se reclama por ampla liberdade, no espectro da competição pelos postos eletivos impõe-se o respeito e a observância do macroprincípio conhecido como o das "eleições disputadas", expresso na cláusula do "free and fair elections", exigindo especial lapidação quanto ao tratamento jurídico que deverá atentar para a garantia de liberdade para: (a) postular cargos eletivos; (b) que os candidatos de disputem respaldo popular, exercendo com a garantia de liberdade o direito de candidatura; (c) os líderes políticos disputarem votos do eleitorado, difundindo o programa e as propostas da respectiva plataforma governamental.

Emerge a questão da elegibilidade, que, a rigor, a todos pertence, a todos os que têm o direito de votar. E mais, assume essa a natureza de direito fundamental. Em climas democráticos, a elegibilidade deve pender para a universalidade. 
Porém, há sempre possibilidade de inserção de determinados lindes, reduzindo-se o acesso a cargos eletivos, quer pela fixação de condições de elegibilidade, quer por força da introdução da figura da inelegibilidade, nas suas variadas e diversificadas modalidades. A ideia, todavia, penetra em cenário político e jurídico com o caráter de evidente excepcionalidade, porquanto implica numa restrição, obscurecendo, temporariamente, o espectro da elegibilidade, erigida a "liberdade pública fundamental". ${ }^{14}$

Considerando o perfil local do próximo pleito de 2012, eleições municipais, importa aqui apresentar as condições de elegibilidade que irão comandar as candidaturas aos postos dos 5.658 municípios, atendendo-se aos indicadores: idade, domicílio eleitoral que vincule o candidato à região que pretende representar, e filiação partidária, de vez que o partido político é detentor do monopólio da candidatura. Em síntese, são elegíveis:

\section{Cargos}

(art. $14, \S 3 .^{\circ} \mathrm{c} / \mathrm{c}$ art. $12, \S 2 .^{\circ}$, da $\left.\mathrm{CF} / 1988\right)$

$\sqrt{ }$ Prefeito e Vice-Prefeito

Nacionalidade brasileira;

Alfabetização;

Filiação partidária: 1 ano;

Idade 21 anos (art. 14, \& 3. , VI, c, da CF/1988);*

Domicílio eleitoral: 1 ano;

Exercício dos direitos políticos.

$\sqrt{ }$ Vereadores

Nacionalidade brasileira;

Alfabetização;

Idade 18 anos (art. 14, § 3. ${ }^{\circ}, \mathrm{VI}, \mathrm{d}$, da CF/1988);*

Filiação partidária;

Domicílio eleitoral: 1 ano;

Exercício dos direitos políticos.

* A idade deve ser demonstrada na data da posse.

14. Nesse sentido, a lição de André e Francine Demichel (Droit Électoral. Paris: LD, 1973), e de Jean-Claude Maclet (Droit Électoral. Paris: PUF, 1989). 
Demais disso, atento ao peculiar perfil restritivo da figura da inelegibilidade, aliás, o nosso Texto Fundamental de 1988 estampa os princípios norteadores desta área, preordenando as linhas mestras das limitações e atribuindo ao legislador complementar ${ }^{15}$ a tarefa de detalhamento das diversas hipóteses da categoria das inelegibilidades proteção, ou seja, um elenco definido a partir de um sentido ético, de tutela da lisura e da autenticidade da consulta eleitoral, voltado a coibir a interferência do poder econômico e da máquina estatal na formação da vontade coletiva.

De se registrar que as hipóteses de inelegibilidade preconizadas pela LC 64/1990 admitem, na sua grande maioria, superação por intermédio do processo de desincompatibilização. Nesta esteira, o próprio documento legal traz os prazos de afastamento da função, cargo ou situação jurídica que implique em óbice à candidatura, condição esta para reconduzir o postulante à condição de elegível. Muito diferente, contudo, o modus operandi da LC 135/2010.

De maior severidade, referida norma dimana da aversão da cidadania em relação à figura do homem político e à corrupção que lhe é acoplada e exclui do processo eleitoral - sem possibilidade de reversão - os candidatos que tenham sofrido condenação, por força de decisão de órgão colegiado, por corrupção eleitoral, abuso do poder econômico, compra de votos, ainda que tenham renunciado ao mandato eletivo antes da condenação. A inovação e a drasticidade da denominada lei "ficha-limpa" causou quase uma verdadeira apoplexia no território jurisdicional com uma avalanche de impugnações às mais diversificadas candidaturas. Afinal não foi aplicada ao pleito de $2010,{ }^{16}$ estreando os seus efeitos apenas em 2012, pois sua constitucionalidade foi confirmada pelo STF em memorável julgamento de 16.02.2012. ${ }^{17}$

O diploma opera acrescentando rigor ao tratamento das hipóteses de inelegibilidade preconizadas pela LC 64/1990. Aumenta os prazos de inelegibilidade, basicamente dos casos de inelegibilidade absoluta (que não pode ser afastada pela mera desincompatibilização), e equipara ao trânsito em julgado, para

15. LC 64, de 18.05.1990 e LC 135, de 04.06.2010.

16. Por decisão do STF, de 23.03.2011 - 5 votos a 6 - a denominada Lei "ficha limpa" não foi aplicada às eleições gerais 2010, em razão do dispositivo constitucional que exige a edição da lei eleitoral um ano antes do pleito para que possa incidir sobre esta consulta eletiva.

17. Em sessão de 16.02 .2012 , o STF decidiu por votação de 7 a 4 pela constitucionalidade da LC 135, de 04.06.2010, e sua aplicação às eleições municipais de 2012, confirmando, destarte, a introdução de novas hipóteses de inelegibilidade, óbices intransponíveis à candidatura. 
fins de criação da inelegibilidade, decisão judicial proferida por órgão colegiado, ou seja, a condenação proferida pelos Tribunais, ainda que pendente de recurso, $e$ expande o catálogo das causas de inelegibilidade.

No tocante ao período de vedação de candidatura, o texto traz o prazo de 8 anos, contado a partir da data da condenação pelo Tribunal, para quase todas as hipóteses. Essas, a seu turno, são alargadas e vêm dotadas de detalhamento aprofundado quanto ao tipo de conduta sancionada, a exemplo da nova redação dada à alínea $e$ do inc. I do art. $1 .^{\circ}$ da LC 64/1990, que agora traz 10 diferentes tipos de crimes gerando inelegibilidade (" 1 . contra a economia popular, a fé pública, a administração pública e o patrimônio público; 2. contra o patrimônio privado, o sistema financeiro, o mercado de capitais e os previstos na lei que regula a falência; 3. contra o meio ambiente e a saúde pública; 4. eleitorais, para os quais a lei comine pena privativa de liberdade; 5 . de abuso de autoridade, nos casos em que houver condenação à perda do cargo ou à inabilitação para o exercício de função pública; 6 . de lavagem ou ocultação de bens, direitos e valores; 7. de tráfico de entorpecentes e drogas afins, racismo, tortura, terrorismo e hediondos; 8 . de redução à condição análoga à de escravo; 9. contra a vida e a dignidade sexual; e 10. praticados por organização criminosa, quadrilha ou bando"), sendo que, neste segmento, o prazo começa a fluir quando cumprida a pena. Isto é: só depois de transcorridos os oito anos do cumprimento da sanção imposta, o óbice à elegibilidade é removido.

Mais ainda, a situação de contas rejeitadas, prevista como figura de inelegibilidade na alínea $g$ do inc. I do art. 1. ${ }^{\circ}$ da LC 64/1990, sofreu endurecimento com o tratamento conferido pela lei "ficha limpa". Agora, não basta encontrar-se a matéria sob a mera apreciação do Poder Judiciário, exigindo-se para a superação da inelegibilidade a sua suspensão ou anulação judicial.

Interessante, nessa esteira, a brecha aberta pelo legislador que reconhece $a$ possibilidade de inibir esses obstáculos à candidatura mediante suspensão do efeito da decisão condenatória obtida em juízo. É o que se depreende da leitura do art. 26-C, um acréscimo efetuado à LC 64/1990 pela nova Lei da "ficha limpa", suavizando sua drasticidade.

Aliás, em se cuidando de contas rejeitadas, inovador o entendimento firmado pelo TSE, em sessão de 01.03.2012, que inseriu novo fator de inelegibilidade, afastando das listas os candidatos que, em eleições passadas, não possam demonstrar ter as respectivas contas aprovadas, invalidando situação anterior, mais flexível, que previa a necessidade tão só da comprovação de ter prestado contas.

Há outros pontos merecedores de destaque nas inovações que emergem do novo figurino da candidatura. Assim, nos moldes estabelecidos pela LC 
135/2010, a renúncia ao cargo, após a apresentação da representação apontando a presença de conduta incriminatória, não mais assume conotação de condição impeditiva de atribuição de inelegibilidade. Esta passa a se afigurar aplicável independentemente da eventual renúncia. No entanto, se a renúncia de parlamentar ou de chefes dos Executivos (alínea $k$ do inc. I do art. 1. ${ }^{\circ}$ da LC 64/1990) ocorrer para fins de desincompatibilização para concorrer a cargo eletivo ou para assumir outro mandato, não se aplicará a inelegibilidade, salvo se comprovada fraude, consoante registra o atual $\S 5 .^{\circ}$ do art. $1 .^{\circ}$ da LC 64/1990, a aludida Lei de Inelegibilidades.

De se registrar, demais disso, que o inovador diploma produzirá um quadro de candidaturas extremamente fluído e instável. Isto porque a decisão proferida em segunda instância, por órgãos colegiados do Judiciário, apanha e incide sobre o candidato no estágio em que se encontrar a respectiva candidatura. Assim, suponha-se que no momento da convenção e do registro da candidatura haja pendência decorrente de mera sentença de primeiro grau; em tramitando recurso dessa decisão, o candidato ainda é elegível e conquista a legenda. Porém, em plena campanha, esta candidatura pode sofrer cancelamento por força do advento de acórdão condenatório emanado de órgão colegiado, o Tribunal. O candidato é retirado da lista, perdendo a legenda. Em seguida, porém, este mesmo candidato vem a obter, por via recursal, suspensão da decisão condenatória. Por mais uma vez, há modificação do quadro das candidaturas, incluindo-se novamente na lista o candidato beneficiado com a suspensão da decisão condenatória. Este movimento de entrada e saída de candidatos nas listas oferecidas ao eleitor poderá se apresentar infindável. E a oscilação fatalmente alcançará, mais que candidato, o próprio mandato político e seu titular.

Muitos, decerto, os tópicos que continuarão ao longo da campanha de 2012 a produzir nevralgias no panorama político. Neste escaninho, certamente se deparará o analista com a recomendação presente no inc. XVI do art. 22 da LC 64/1990, por força das inovações da Lei da "ficha limpa". Esse orienta o aplicador da lei, para, visando à configuração do ato abusivo, verificar "apenas a gravidade das circunstâncias que o caracterizam". Construído em textura imprecisa e indefinida, parece-nos que, em primeiro passo, deveria se definir o exato conteúdo da expressão "gravidade das circunstâncias", sob pena de deixar ao sabor de cada julgador, de sua ideologia e simpatias políticas, o poder de retirar $o$ status de elegibilidade dos postulantes a cargos eletivos, o seu direito fundamental de atuar em cena política no exercício do sufrágio passivo. Isto seria absurdo.

No campo das candidaturas avulta com intensidade, como acima registrado, a obrigatoriedade de filiação partidária, erigida mesmo à condição de elegibilidade, ex vi da norma do art. $14, \S 3 .^{\circ}, \mathrm{V}$, da CF/1988. É que o partido político se oferece como mecanismo apto a promover o enquadramento dos atores que 
se movimentam em cena no momento eleitoral. Atribui-lhe o legislador constituinte, assim, a exclusividade na apresentação das candidaturas.

A condição de candidato, pois, depende de escolha em convenção partidária e esta detém a faculdade de conceder ou não legenda. O monopolístico tratamento quanto à concessão de legenda para fins de candidatura foi reforçada por decisão do STF, ao apreciar a ADIn 2.530-9/DF, suspendendo liminarmente o disposto no $\S 1 .^{\circ}$ do art. $8 .^{\circ}$ da Lei $9.504 / 1997$, que assegurava aos parlamentares $^{18}$ o direito ao registro da candidatura - em reeleição - pelo mesmo partido. Restou, no entanto, mantido o direito do candidato de conservar o número de identificação utilizado na eleição anterior (art. 15, § 1. ${ }^{\circ}$, da Lei 9.504/1997).

Aliás, a condição de aspirante a cargo eletivo importa em verdadeiro status - $o$ da candidatura. Para atingi-lo, vários os degraus numa longa trajetória. O percurso, de fato, tem como ponto de partida o implemento da condição de filiação a partido político e da exigência de domicílio eleitoral. Um ano antes da data das eleições. E é, de fato, um ano antes que se dá o início do processo eleitoral. ${ }^{19}$

Atendidos esses requisitos o pré-candidato começa a campanha para a conquista de sua vaga na lista partidária de candidatos. O próprio legislador reconhece a condição de pré-candidatura que será proposta à convenção partidária para escolha. Autoriza, porém, um reduzidíssimo período de campanha intrapartidária, ${ }^{20}$ ignorando que, ao longo de todo este período compreendido entre 7 de outubro do ano anterior ao pleito e o dia da realização da convenção (10 a 30 de junho do ano de realização da consulta eleitoral), o pré-candidato atua na conquista do status de candidato a posto eletivo. Trata-se de postulante que, no entanto, marca presença como ator do cenário eleitoral. É certo, não alcançou o status de candidato, mas já desempenha e exerce o seu poder de sufrágio passivo, um direito que deve vir assegurado pela cláusula do "free and fair elections". Não surpreende, pois, o vasto elenco de impugnações e acusações por propaganda antecipada, quase sempre ignoradas pelos Tribunais Superiores ou até mesmo pelos candidatos que preferem arcar com a multa a permanecer silentes e longe do eleitorado que pretendem conquistar. ${ }^{21}$

18. Deputados federais, deputados estaduais, deputados distritais e vereadores.

19. Nesta direção, basta verificar que o calendário das eleições de 2012 já foi elaborado e isto desde 2011 (Res. TSE 23.341/2011).

20. O $\S 1 .^{\circ}$ do art. 36 da Lei 9.504/1997, prevê a possibilidade de divulgação de campanha publicitária por parte do pré-candidato pelo período de 15 dias precedentes à data da convenção.

21. Veja-se o exemplo da Representação $184 / 2008$, promovida contra a então candidata a Prefeitura do Município de São Paulo, Marta Suplicy. Condenada em $1 .^{a}$ instância, o 
Privilégio da agremiação partidária, esta formaliza a candidatura por listas ou chapa, em se tratando da candidatura a posto do Executivo. Estas são levadas ao registro perante a Justiça Eleitoral e, assim, a candidatura passa a ser promovida e regida pelo partido que é titular da lista.

Paradoxalmente, no Brasil, a empatia do eleitor com a figura do candidato constitui característica própria do comportamento da cidadania. A ligadura afigura-se mais sólida e real. No último pleito, esta tendência restou clara e houve um evidente direcionamento do voto em favor de um candidato e não da legenda a albergar a candidatura. Expressiva, nesta esteira, a atribuição de votos $\left(1 .^{\circ}\right.$ e 2. ${ }^{\circ}$ mais votados dos Deputados Federais por São Paulo) a duas polêmicas figuras: a primeira, o palhaço Tiririca que, disputando o pleito por um dos partidos "nanicos", o PR, conquistou a simpatia dos eleitores, sendo agraciado com o voto de 1.353.820; a segunda, o então Vereador Gabriel Chalita que, embora tenha abandonado o PSDB, um dos partidos de maior expressão no cenário político, filiando-se ao mediano PSB - sem sofrer perda da vereança por infidelidade partidária - conquistou 560.022 votos.

E mais que opção por legenda partidária, o eleitor de 2010 conferiu o seu voto atento ao interesse de sua região (voto regional) ou atribuindo sua preferência a candidaturas representativas de setores determinados da sociedade, isto é, candidaturas vinculadas a bases corporativas, a exemplo do grupo dos bancários, à Igreja, o voto de fundo religioso, a grupos de opinião, sustentando postulantes defensores da revitalização dos serviços de saúde, segurança, educação etc. ${ }^{22}$ Longe se manteve o eleitor da visão partidária, do seu programa ou da ideologia subjacente.

\section{Candidatura e reeleição}

Outro aspecto digno de registro no que tange ao distanciamento do eleitor da constelação partidária é constatado quando se examina o instituto da reeleição e sua incorporação ao comportamento eleitoral. A viabilidade da reeleição

TSE reformou e arquivou a representação. De qualquer forma, a candidata seguiu em frente com a campanha sendo derrotada nas urnas. Em março de 2012, no entanto, o TSE condenou a candidata Dilma Roussef e o partido PT por propaganda antecipada, aplicando multas à agremiação, à candidata e, ainda, determinando a suspensão da propaganda partidária no $1 .^{\circ}$ semestre do ano de 2012 (Fonte: TSE, Representação 110.994/DF e Representação 123.110/DF, rel. Min. Nancy Andrighi).

22. Ver neste sentido reportagem publicada pelo O Estado de S. Paulo, 07.10.2010, p. A18. 
foi inaugurada entre nós por força da EC 16, de 04.06.1997. Esta inovou no tocante ao tratamento histórico e tradicionalmente adotado no Brasil, que preconizava a irreelegibilidade. ${ }^{23}$ A nova ordem, porém, suavizou a vedação para permitir que os titulares dos cargos de Presidente da República, Governador de Estado e Prefeitos venham a postular por mais uma vez, em linha subsequente, o mesmo posto. ${ }^{24}$

Com efeito, a regra de recondução possível do chefe máximo do Executivo, para mais um mandato consecutivo, encontra guarida na evolução do sistema presidencialista norte-americano, quando, no ensejo de se recusar "replay" à pretensão do Presidente Roosevelt de concorrer a um terceiro e quarto mandatos, foi consagrada, em esfera constitucional, com o advento e a ratificação da Emenda XXII, a possibilidade de se pleitear uma e uma só vez a reeleição.

No panorama sul-americano à época da edição da mencionada EC 16/1997, contudo, a prática afigurava-se rara e, de certa forma, hostilizada. Até porque atinge e pode produzir danos ao princípio da alternância, a par de facilitar e introduzir o risco do continuísmo e de deterioração do polo de poder, por força da ação corrosiva de sua concentração, por um longo período, nas mãos de um grupo ou de um só homem.

De qualquer forma, o impacto da reeleição deflagrou, em relação ao corpo eleitoral, uma nova postura, conduzindo a opções políticas considerando programas governamentais, ponderando sobre a conveniência de se assegurar continuidade às políticas públicas em desenvolvimento ou, em não as aprovando, decidir pelo novo, por uma outra proposta de ação e metas de governo. A escolha que a cidadania é convocada a realizar se posiciona, agora, entre programas de governo.

Forçoso convir que o cidadão apreciou e alinhou-se sem dificuldades a esta recente perspectiva de expressar preferência política por um determinado projeto de governo. Assim, os dois últimos Presidentes da República do Brasil foram contemplados com a aprovação popular, conquistando mais um mandato. E, no quadro dos Estados-membros, no pleito de 2002, foram detectadas 8 candidaturas ao governo do Estado a pleitear a reeleição, dos quais 4 sagraram-se vitoriosos nas urnas ${ }^{25}$ nas eleições de 2006, 16 candidaturas se apresentaram

23. A regra da irreelegibilidade estreia entre nós com o texto da Constituição Republicana de 1891 (art. 43), afigurando-se ausente tão só na Carta de 1937.

24. Art. 14 , § 5. ${ }^{\circ}$, da CF/1988 (reeleição).

25. Conquistaram mais um mandato, sucessivo, os Governadores: Geraldo Alckmin (São Paulo), Joaquim Roriz (Brasília/DF), Flamarion Portela (Roraima), Zeca do PT (Mato Grosso do Sul). 
para reeleição, sendo reeleitos 10; e, na consulta eletiva de 2010, dos 20 candidatos à reeleição, 18 sagraram-se vitoriosos. ${ }^{26}$

Certo é que a reeleição estreia entre nós, já em 1997, sob a acusação de introduzir o desequilíbrio na competição eleitoral, fato que, dúvida não há, pode se tornar um perverso efeito colateral do instituto. Para tanto, o cuidadoso tratamento legal restritivo de que foi merecedor este aplicativo do sistema majoritário que comanda a seleção para os cargos do Executivo (federal, estadual e municipal). No entanto, não há que se ignorar que o pleito presidencial de 2010 foi alvo de múltiplas denúncias quanto à utilização da máquina estatal e dos programas governamentais para a campanha da sucessora do antigo Presidente e não se tratava de reeleição. O uso da máquina e do poder politico por parte da força ou do partido político situacionista conforma uma deformação do standard conhecido como free and fair election em qualquer plano eleitoral, independentemente de se tratar ou não de reeleição.

De qualquer forma, o impacto da reeleição deflagrou novas limitações às campanhas e, destarte, à liberdade de divulgar posturas e plataformas políticas, disputando a simpatia, a confiança e o voto dos eleitores. Assim é que, a Lei 9.504, de 30.09.1997, dedica todo um capítulo às "condutas vedadas aos agentes públicos em campanhas eleitorais" (arts. 73 a 78), visando impedir o uso da máquina estatal, principalmente, por parte dos candidatos à reeleição. E as restrições introduzidas foram objeto de reforço por parte da Justiça Eleitoral, ao baixar as respectivas instruções, culminando por impedir, de certa forma, até uma adequada segurança das autoridades, quando em campanha política. Dentre tais proibições pode-se destacar:

- a impossibilidade de participação das campanhas políticas de assessores ou funcionários subordinados ao pretendente à reeleição, impondo-lhes, para tanto, prévio afastamento do cargo, o que na prática impunha a realização de atos de campanha eleitoral com vistas à recondução de uma equipe governamental e para a continuidade do programa desenvolvido por essa mesma equipe, porém sem a equipe - essa tarefa restou atribuída com exclusividade ao respectivo chefe;

- a impossibilidade de uso de veículo oficial para comparecer a atos de campanha - avião ou automóvel. Paradoxalmente, o corpo de segurança po-

26. O tema reeleição vem tratado com propriedade por Deliberador, Giuliano Savioli; Komata, Nicanor Barry. Reeleição nas eleições municipais de 2008. In: CaGgiano, Monica Herman (coord.). Comportamento eleitoral. Barueri: Cepes/Manole, 2010. Série Culturalismo Jurídico. 
deria se deslocar com veículos oficiais e, na hipótese de aeronave, o usuário restaria obrigado a ressarcir o erário público pelo valor da viagem. A regra logo fez a primeira vítima, o Ministro da Saúde que se utilizou de aeronave da Companhia Energética de São Paulo para se deslocar de São Paulo a Piracicaba, para reunião de "cunho político-partidária", como alcunhado referido encontro, ensejando a instalação de processo judicial e condenação da autoridade;

- neutralidade por parte da equipe de segurança que eventualmente acompanhar a autoridade a eventos de campanha, no sentido de lhe restar vedada a possibilidade de distribuição de material ou ato que pudesse ser considerado como de propaganda do candidato;

- aparelhos de telefone e fax do candidato a reeleição não podem ser utilizados para contatos de campanha;

- residência oficial não podendo ser utilizada para jantares ou eventos que possam vir a ser qualificados como reuniões de campanha político-eleitoral.

Digna de nota essa última hipótese arrolada a partir do elenco restritivo a incidir sobre os postulantes a mais um mandato. Isto porque não há como impedir alguém de receber, no local da sua moradia, quem quer que seja. Não dando abrigo a criminosos, a inviolabilidade do domicílio é princípio constitucional e assegurado, também, o direito à privacidade. Portanto, ilusório que tal norma viria a impedir a realização de jantares e almoços com personalidades importantes na trajetória da reeleição. Nem há que se falar, ademais, que a técnica "jantar com o Presidente" configura uma das mais antigas e tradicionais no catálogo do "Fund Rising", vindo a ser catalogada pelo Prof. Herbert E. Alexander como financiamento "on the cash and calorie plan". ${ }^{27}$ Absurda a regra, ainda, porque impraticável uma eficaz fiscalização, passando a se afigurar muito difícil a comprovação de eventual incidência. Reflete um dispositivo fadado a servir de simples fachada e a uma triste permanência no papel.

Restou vedado mais: publicidade institucional, salvo em caso de grave e urgente necessidade pública, assim entendida pela Justiça Eleitoral, e quaisquer pronunciamentos em cadeia de rádio e televisão fora do horário eleitoral gratuito, excetuando-se as hipóteses de urgência, a critério da Justiça Eleitoral (art. 73, VI, $b$ e $c$, da Lei 9.504/1997), postura legislativa que reintroduziu, entre nós, a censura, abolida pela Constituição Federal de 05.10.1988.

27. Money in politics. Washington: PAP, 1972; e Financing politics. Washington: Congressional Inc., April 1978. 


\section{Candidatura em coligação}

A busca por espaço na mídia e maior potencial eleitoral constituem fortes razões para que as agremiações de menor expressividade ingressem na disputa, basicamente, por via de coligações, com o objetivo, em princípio, de concorrer para a ampliação do tempo de antena dos mais poderosos, conquistando, em contrapartida, recursos de marketing e espaço mais promissor para os seus próprios candidatos. ${ }^{28}$ Por vezes, porém, sua participação tem por escopo mero ato de presença eleitoral, presença que, quando não produz efeitos nocivos sobre a campanha, por privilegiar, a partir da penumbra, candidato de maior potencial, é salutar para o robustecimento da participação política e ampliação das possibilidades de exercício da cidadania.

Com efeito, a figura da coligação - a formação de grupos de partidos para a disputa eletiva - revela uma real e concreta ferramenta para o fortalecimento dos partidos quando em campanha eleitoral, buscando assegurar um quadro de equilíbrio na disputa pelo poder político às médias e pequenas organizações partidárias, muitas vezes apenas engatinhando ou embrionárias.

Fato é que o partido tem por escopo e finalidade básicas alcançar o poder. Diferentemente, pois, das demais associações e grupos da sociedade civil organizada que não perseguem exatamente esta finalidade, embora de relevância a sua participação em cenário político, a agremiação partidária detém um objetivo definido e procura entrar na arena da competição, na plataforma eleitoral, preparada e munida do instrumental e potência necessários para o atingimento dessa meta. A viabilidade de se apresentar candidaturas suportadas por diversas forças partidárias, reunidas em coligação, constitui um elemento essencial de robustecimento do partido, tornando possivel o ingresso e a participação política - pelo exercício do sufrágio passivo - a candidaturas que, isoladamente, não apresentariam quaisquer condições de disputa e de reivindicar o voto do eleitorado.

Consciente dessa realidade, os ordenamentos jurídicos, em geral, simpatizam com o instituto, autorizando a coligação de partidos para a apresentação das candidaturas, quer nos pleitos proporcionais, que nas eleições que se processam pelo método majoritário. O constituinte de 1988, de sua parte, foi extremamente benevolente ao tratar da matéria. No § $1 .^{\circ}$ do art. 17 da CF/1988,

28. Esta realidade vem retratada no pleito de 2010, quando o PT reforçou em 5\% o seu tempo de propaganda da candidata à Presidência, com a coligação realizada com PSC, PTC e PRB, desembolsando a favor dessas agremiações aliadas cerca de 5,8 milhões de reais (cf. notícia do jornal O Estado de S. Paulo, 18.05.2011, p. A6). 
assegurou às agremiações "autonomia para definir sua estrutura interna, organização e funcionamento (...)". E, de fato, parece-nos imprescindível o instituto num panorama propício à proliferação das agremiações político-partidárias. ${ }^{29}$ Mas, em 2002, por via de Resolução, o TSE introduziu sérias limitações à prática das coligações, determinando a obrigatoriedade de observância da regra de verticalização que perdurou até o advento da EC 52/2006, que iniciou sua eficácia só em 2010, colocando em nível constitucional, pela reformulação do mencionado $\S 1 .^{\circ}$ do art. 17 da CF/1988, a garantia dos partidos de autonomia para "adotar os critérios de escolha e o regime de suas coligações eleitorais, sem obrigatoriedade de vinculação entre as candidaturas em âmbito nacional, estadual, distrital ou municipal (...)".

Prevalece, portanto, a regra da liberdade partidária de firmar coligações norteadas apenas pela conveniência e oportunidade. Não importa a ideologia, a eventual simetria de programas ou plataformas governamentais. A figura da coligação emerge como mero instrumento de competição eleitoral, observadas, de certo, as condições estatutárias e o disposto na lei eleitoral para fins de apresentação das candidaturas.

\section{O SISTEMA ELEITORAL: PONTO DE TENSÃO}

Um dos pontos merecedores de tensa crítica foi o sistema eleitoral brasileiro, utilizado desde 1932, e que foi aplicado também à consulta eletiva de 2010 - o método proporcional - para os postos dos Legislativos (Câmara dos Deputados e Assembleias Legislativas). À técnica empregada é que acabaram sendo atribuídos fenômenos próprios de um processo eleitoral timbrado pela ideia do desprestígio do homem político. A vitória do palhaço Tiririca que, diante de sua expressiva votação, concorreu para a eleição de mais quatro deputados do seu micropartido, o PR, resultou em polêmico debate acerca das falhas e defeituosidades desta fórmula.

Em verdade, complexo e sensível é o segmento em que reina a técnica da proporcionalidade - o campo das eleições parlamentares. Isto porque, embora o

29. O quadro partidário brasileiro apresenta-se bastante pulverizado. Em 1996 albergava 32 partidos políticos - 26 com registro definitivo, 4 com registro provisório e 2 com requerimento em tramitação, solicitando capacitação jurídica. Hoje se convive com 29 partidos, sendo 7 de grande e médio porte e o restante inseridos sob o rótulo de nanicos. Há que se registrar de forma especial a criação do PSD, partido de média grandeza apesar de sua recente criação (TSE, Registro de partido político 141.796, j. 27.09.2011, rel. Min. Fátima Nancy Andrighi). 
modelo seja o que mais se afeiçoa à expectativa de representação do maior número de setores da comunidade social, ${ }^{30}$ as peculiaridades do padrão adotado, na paisagem doméstica brasileira, enseja relevantes desvios e críticas.

Com efeito, o método desenhado pelo legislador aponta para a técnica proporcional, empregando o subsistema do Quociente Eleitoral, acoplado ao Quociente Partidário, sendo a partilha das sobras operacionalizada pelo método da maior média. ${ }^{31}$ Importa, na verdade, em três diferentes operações, todas voltadas a privilegiar a figura do partido político e, porque não dizer, daqueles de maior densidade eleitoral, porquanto na distribuição das sobras são os partidos com maior votação que acabam sendo contemplados com o maior número de cadeiras parlamentares restantes (as sobras).

O sistema, como já anotado, gira em torno da entidade - partido político. Retira da disputa as agremiações que não alcancem o QE (Quociente Eleitoral), independentemente da boa votação que alguns de seus candidatos possam ter obtido. De outra parte, acaba contemplando com cadeiras parlamentares os partidos ou coligações que, no conjunto de candidaturas apresentadas, maior número de votos alcançaram. E esta operação pode, por vezes, resultar na produção de verdadeiras ficções eleitorais, a exemplo do caso Prona ${ }^{32}$ que escandali-

30. O modelo conhecido como sistema proporcional gira em torno da ideia de que o número de votos atribuídos a um partido deve ser proporcional ao número de cadeiras por esse obtido, visando - numa perspectiva de assegurar equidade e justiça no campo da disputa eleitoral - conferir a cada uma das agremiações político-partidárias a sua real cota de participação no processo de distribuição das vagas do Legislativo. Costuma-se atribuir a Thomas Hare, advogado londrino, o mérito da introdução da ideia da proporcionalidade aplicável à esfera eleitoral. Na verdade, o sistema foi aplicado pela primeira vez na Bélgica, em 1899, com a adoção da proposta do Professor de Direito e Matemático Victor d'Hondt a subsidiar projeto de lei apresentado pelo Ministro da Justiça, Van den Heuven. V. nosso Sistemas eleitorais x representação política. Brasília: Senado Federal, 1987. p. 149 e ss.

31. Arts. 106, 107, 108 e 109 da Lei 4.737/1965 (Código Eleitoral). Ver o mecanismo do sistema do Quociente Eleitoral acoplado à técnica da maior média, para as sobras, no nosso Sistemas eleitorais $x$ representação política cit.

32. Pois bem, no episódio vivenciado pelo Prona (Eleições 2002), o partido conquistou 6 cadeiras parlamentares (Câmara Federal) apoiado, apenas e tão só, na votação obtida pelo seu líder, Enéas (1.572.292). Os demais eleitos não detêm o menor nível de representatividade. Obtiveram um número de sufrágios absolutamente irrisório (Amauri R. Gasques: 18.409 votos; Irapuan Teixeira: 672 votos; Elimar: 483 votos; Ildeu Araújo: 382 votos; Vanderlei Assis: 275 votos) e muito inferior à média de votos necessária para se eleger, isto é, de aproximadamente 100.000. 
zou os eleitores, em 2002, com a deturpação verificada no grau de representatividade dos eleitos e, em 2010, com o caso Tiririca.

A ocorrência dos fenômenos Prona e Tiririca demonstraram efeitos perversos para a representação de padrão proporcional aplicado com vinculação total ao quadro partidário. Provocou intensa polêmica e ressuscitou o debate sobre a reforma política, reclamando um especial debruçar sobre os mecanismos da representação política preconizados pela Constituição. A temática da reengenharia eleitoral e partidária ingressou, por mais esta vez, pauta do Legislativo, retirando-se das gavetas a proposta do voto distrital, ou distrital misto, sempre presente no bloco das mutações propostas. Isto na expectativa de que a nova técnica viria minimizar as possibilidades de ocorrência dessa espécie de desvio na representação política.

É que o voto distrital, na sua feição mista - o modelo alemão - implica no provimento de $50 \%$ (poderia ser qualquer outra porcentagem - 25\%, 60\%, 40\%) das cadeiras parlamentares pelo voto majoritário puro, sufrágio uninominal, votando-se no candidato e sagrando-se vitoriosos aqueles que, de per si, conquistarem o maior número de sufrágios. O restante das vagas - para distribuição - atenderia a técnica proporcional, sede em que deve se levar em consideração o número de votos obtidos pela legenda, procedendo-se à partilha dos assentos restantes na conformidade do número de sufrágios conquistados pelo partido.

Frise-se, todavia, que a modelagem distrital não se encontra imune a manobras que conduzam à deterioração e desvios. De confortável acomodação à técnica do gerrymandering ${ }^{33}$ ou à geometria eleitoral, pode levar a favorecimentos, notadamente da força política situacionista que promove o desenho ou o redesenho dos distritos. É o que ocorreu na Venezuela, na eleição parlamentar de 26.09.2010, quando o Presidente pelo redesenho dos distritos eleitorais obteve a maioria de modo manifestamente artificial.

Pois bem, além da conhecida e debatida técnica do "voto distrital", que encontra importantes simpatizantes em cenário político, mas que, a cada nova legislatura, ingressa na pauta parlamentar por breves períodos para, a seguir,

33. A técnica conhecida como Gerrymander penetra no elenco das medidas deflagradoras de desigualdades eleitorais oriundas de divisões geográficas. Idealizada por Elbridge Gerry, Governador de Massachussuts que, em 1842 dividiu o Estado em distritos atendendo ao formato de uma salamandra com o escopo de priorizar os interesses do seu partido. Ver a respeito o nosso Sistemas eleitorais $x$ Representação política, op. cit., p. 78 . 
retornar à penumbra das gavetas do nosso Congresso, ${ }^{34}$ oportuno se nos afigura o exame mais detido do método misto, conhecido como voto único transferível, advogado, já ao final do século XIX, por Thomas Hare. ${ }^{35}$ É que referido sistema autoriza uma valoração efetiva da vontade política expressa nas urnas pelo eleitor, abrindo, a seu favor, a possibilidade de indicar preferências: a primeira, a segunda, a terceira... Demais disso, viabiliza uma partilha das cadeiras, entre os candidatos, mais democrática e com maior enfoque para a exigência da representatividade. Neste contexto, o eleitor deve sufragar um só candidato; o seu voto, no entanto, é transferido para outro candidato de sua preferência, caso aquele que constou como primeira preferência tenha sido eleito ou, ainda, tenha obtido um número muito pequeno de votos, inferior ao exigido, e que não detém condições de se eleger.

A técnica se oferece, talvez, de maior complexidade. Prevê uma primeira operação, por intermédio da qual define-se o Quociente Eleitoral (QE), e uma atividade sucessiva compreendendo operações complementares de mensuração e atribuição das preferências. No entanto, sua aplicação evitaria a produção de bancadas de ficção, sem qualquer consistência eleitoral e de questionável representatividade.

Parece-nos que, antes de encerrar este estudo, necessário o registro de que desde a sua estreia entre nós, em 1932, com o advento do Dec. 21.076/1932 (Código Eleitoral), a representação proporcional sofreu severos ataques e críticas. J. H. Meirelles Teixeira, examinando a Constituição de 1946 e, já àquela época, proclamando a imperiosidade de uma reforma política, ${ }^{36}$ qualifica a opção realizada pelo constituinte como o "maior erro político da nossa história contemporânea", notadamente, em razão "das lamentáveis consequências". No entanto, neste percurso de 80 anos, poucos e excepcionais os desvios. E quando constatados, verifica-se a clara presença do eleitor que voluntariamen-

34. Nova comissão para estudo da reforma política foi designada pelo Senador José Sarney, sendo nomeado o Senador Francisco Dornelles como o seu Presidente. Isto em janeiro de 2011, sendo instalada em 22 de fevereiro do mesmo ano. Com propostas similares às anteriores, a exemplo do fim das coligações, do instituto da reeleição, reformulação do voto proporcional, financiamento público das campanhas etc., referido colegiado ainda não encerrou os trabalhos. E as eleições de 2012 vão se processar sob as regras tradicionais, em vigor (site UOL, 13.04.2011).

35. O sistema do voto único transferível é aplicado na Irlanda e em Malta.

36. Meirelles Teixeira, J. J. A reforma constitucional, político partidária e eleitoral e o futuro da democracia no Brasil. Revista dos Tribunais. vol. 328, p. 3-67. São Paulo: Ed. RT, fev. 1963. 
te lhe dá causa, quer por manifestar o seu protesto contra o quadro político, quer por se identificar com a proposta apresentada. Mas o voto é soberano e a manifestação de vontade política deve ser considerada.

Enfim, um sistema eleitoral deve ser simples e oferecer ao cidadão um instrumento apto a garantir sua participação no processo decisional. Certamente a representação proporcional operacionalizada pelo sistema praticado no Brasil - Quociente Eleitoral acoplado ao Quociente Partidário e acrescido da distribuição das sobras pela técnica da maior média - atende a essa exigência. O eleitor já está acostumado e, portanto, apto a depositar conscientemente o voto na urna. Porém, se a intenção é assegurar o cômputo da preferência manifestada pelo eleitor na cédula de votação, talvez o voto único transferível, conquanto de maior sofisticação, se acomodaria melhor à expectativa de efetiva participação política.

\section{Pesouisas do Editorial}

\section{Veja também Doutrina}

- Corrupção e financiamento das campanhas eleitorais, de Monica Herman Salem Caggiano - $R D C l$ 41/215;

- Justiça eleitoral e improbidade administrativa, de Rogério Medeiros Garcia de Lima $R D C l$ 41/256;

- 0 voto como direito fundamental republicano, de Roberto Rosas - RDCl 57/49;

- Partidos políticos, de Paulo Hamilton Siqueira Jr. - RT 909/129; e

- Presunção de inocência para candidatos acusados análise através da doutrina e da jurisprudência, de Wilson Rezende Balada - RT 911/263. 